\title{
Brief Biography of Liz Lochhead
}

Liz Lochhead was born in Motherwell, Lanarkshire on 26 December 1947, the first child of John Lochhead who worked as a local government clerk and his wife Margaret Forrest. The family moved to Newarthill in 1952 where Lochhead went to primary school and her sister was born in 1957. As a secondary school pupil she went to Dalziel High School in Motherwell and in 1965 matriculated in the Glasgow School of Art, graduating in 1970. During her time as an art student Lochhead began to attend Stephen Mulrine's writers' workshop and to write poetry. From there she worked as an art teacher in Glasgow, Bristol and Cumbernauld until the watershed year of 1978 when she was awarded the first Scottish/Canadian Writers' Exchange Fellowship and left Scotland for Toronto and America. Her first collection of poetry, Memo for Spring, which won a Scottish Arts Council Book Award, was published in 1972, and her second, Islands, in 1978 which was also the year in which she wrote and performed, with Marcella Evaristi, her feminist revue Sugar and Spite at the Traverse Theatre in Edinburgh.

Lochhead married the architect Tom Logan in 1986 and they settled in the West End of Glasgow. She continued to publish poetry throughout the 1980s, with The Grimm Sisters in 1981, Dreaming Frankenstein $\mathcal{E}$ Collected Poems in 1984 and a new collection of performance pieces, True Confessions and New Clichés in 1985. At the same time, she was experimenting in fulllength theatre, adapting Frankenstein for the stage as Blood and Ice (Traverse Theatre, Edinburgh and Belgrade Theatre, Coventry) in 1982; Shanghaied for the Ayrshire-based Borderline Theatre in 1982; Rosaleen's Baby for the Scottish Youth Theatre in 1983; and Dracula for the Royal Lyceum Theatre, Edinburgh in 1985. Her Scots adaptation of Molière's Tartuffe premièred at the Royal Lyceum Theatre in 1986. Mary Queen of Scots Got Her Head Chopped Off, to mark the 400th anniversary of Mary's death, was performed by Communicado Theatre Company at the Edinburgh Festival in 1987.

From here, Lochhead's work branched in several directions. She published three further collections of poetry, Bagpipe Muzak in 1991, The Colour of Black and White: Poems 1984-2003 in 2003 and A Choosing in 2011. Her 
more recent adaptation of theatrical classics started with Theatre Babel's Medea in 2000, which gained the Saltire Society Scottish Book of the Year award. This was followed by Miseryguts, a version of Molière's Le Misanthrope set around the Scottish Parliament and performed at the Royal Lyceum in 2002, Thebans (after Sophocles) in 2003 and Educating Agnes, a version of Molière's School for Wives/L'École des Femmes in 2008, the latter two with Theatre Babel. She also wrote a sequence of original dramas: Cuba (1997, for the 35th anniversary of the Cuban missile crisis), a play for young people commissioned by the Royal National Theatre; Elizabeth (1998), a sequel to Shanghaied, for the Royal Lyceum, where both were played together under the joint title Britannia Rules; the romantic comedies Perfect Days (1998) and Good Things (2004); and the 'theatrical event' Edwin Morgan's Dreams and Other Nightmares for Glasgay! (2011).

Her husband died after a short illness in 2010.

She was appointed an honorary fellow of the Association for Scottish Literary Studies in 2010 and Scotland's Makar, its national Poet Laureate, in 2011. 